\title{
Rancangan Strategi Pemasaran Usaha Mikro Kecil Menengah Kerupuk Multisari
}

\author{
SERA NINGSIH $^{1}$, TRI HANDAYANI ${ }^{2}$ \\ ${ }^{1,2}$ Politeknik Negeri Bengkalis \\ E-mail : trihandayani@ polbeng.ac.id
}

\begin{abstract}
The purpose of this project is to know marketing strategy on micro small and Medium Enterprises Multisari crackers, to know product strategy, to know price strategy, to know place strategy, to know promotion strategy for implementing the business. The Research methods consists of the project preparation plan, project implementation plan, project completion plan and project reporting plan. The risult of this project in the form of mprovement of marketing strategy through marketing mix strategy on the micro small and Medium Enterprises Multisari crackers with improvement of the label design, the packaging size and Product diversification, and improvement of promotions. Reporting project consists of reporting Business Marketing Strategies and reporting activities of Business Marketing Strategies of Multisari crackers.
\end{abstract}

Keywords: Marketing Strategy, marketing mix, micro small and Medium Enterprises.

Usaha mikro kecil dan menengah (UMKM) merupakan penyumbang pertumbuhan ekonomi suatu daerah, semakin banyak UMKM berkontribusi akan berpengaruh kepada peningkatan aspek ekonomi dan sosial yang lainnya pada suatu daerah seperti adanya peningkatan kesempatan/ lapangan pekerjaan, peningkatan taraf hidup masyarakat, daya beli yang semakin meningkat, peningkatan kesejahteraan sehinggan pada akhirnya meningkatkan pertumbuhan ekonomi suatu daerah. Oleh sebab itu pemerintah sangat mendukung dan menggalakkan pertumbuhan UMKM dengan melakukan berbagai program yang menggalakkan masyarakat untuk berwirausaha. Namun UMKM yang sudah berdiri dan dalam tahap merintis usaha harus diberikan pendampingan, hal ini bertujuan agar UMKM yang ada mampu menjalankan usahanya secara profesional, mampu bersaing dengan menerapkan strategi pemasaran yang tepat serta mampu menarik minat konsumen. Sehingga UMKM yang ada mampu bertahan dan terus eksis.

Salah satu UMKM yang ada adalah UMKM penghasil kerupuk dimana kerupuk merupakan panganan ringan ciri khas indonesia bahkan menjadi ciri khas suatu daerah tertentu. Semakin banyak peminat kerupuk mempengaruhi banyak industri kerupuk yang berkembang pesat di daerah-daerah khususnya Bengkalis, baik industri kerupuk yang langsung dapat dinikmati ataupun yang masih setengah jadi (krecek). Hal ini menyebabkan masyarakat lebih inovatif dan kreatif untuk berwirausaha menciptakan panganan kerupuk.

Usaha Kerupuk Multisari merupakan UMKM yang bergerak dalam menghasilkan beberapa jenis kerupuk mentah. Usaha Kerupuk Multisari beralamat di Desa Pangkalan Batang Kecamatan Bengkalis. Usaha kerupuk ini berdiri sejak tahun 2005 yang dikelola secara keluarga. Keberadaan usaha Kerupuk Multisari sudah terkenal di sebagian masyarakat Bengkalis dengan usaha kerupuk yang dihasilkannya terutama produk andalannya, yakni kerupuk terasi sagu. Usaha Kerupuk Multisari merupakan usaha kerupuk yang proses pembuatannya mengunakan $100 \%$ bahan alami tanpa pengawet.

Usaha Kerupuk Multisari menghasilkan beberapa jenis kerupuk 
yakni, kerupuk terasi sagu, kerupuk ikan parang dan kerupuk udang. Kerupukkerupuk yang dihasilkan usaha Kerupuk Multisari ini semuanya menggunakan bahan alami tanpa pengawet.

Saat ini usaha kerupuk Multisari masih dikelola secara sederhana, Kemasan produk yang digunakan sudah cukup memadai namun label yang digunakan usaha Kerupuk Multisari masih cukup sederhana dan belum mencerminkan ciri khas produk serta sangat sederhana dalam menetapkan harga produk. Dalam hal Saluran distribusi usaha Kerupuk Multisari hanya ada dibeberapa tempat seputar kota Bengkalis dan hanya menggunakan saluran distribusi langsung, belum mencapai pangsa pasar yang luas dan tersegmen serta belum terdistribusi dengan baik. Padahal UMKM ini memiliki cita rasa yang enak dan memiliki prospek untuk dikembangkan.

$$
\text { Menurut Sofjan Assauri }
$$

(2010:168), strategi pemasaran pada dasarnya adalah rencana yang menyeluruh, terpadu dan menyatu dalam bidang pemasaran, yang memberikan panduan tentang kegiatan yang akan dijalankan untuk dapat tercapainya tujuan pemasaran suatu perusahaan. Untuk itu diperlukan strategi pemasaran yang tepat agar pemasaran usaha Kerupuk Multisari dapat berkembang lebih luas lagi, hal ini dapat dilakukan dengan merencanakan strategi pemasaran yang tepat, dengan merubah bentuk kemasan yang baru, menambah saluran distribusi yang baru, menetapkan harga produk yang baru dan melakukan promosi. Dengan begitu penulis berharap dengan strategi yang tepat serta melakukan beberapa perubahan pada usaha Kerupuk Multisari, dapat menarik perhatian dan minat masyarakat yang tinggi akan usaha kerupuk.

Penelitian yang dilakukan oleh Kiumarsi K, dkk (2014) dengan judul penelitian "Marketing strategies to improve the sales of bakery products of small-medium enterprise (SMEs) in Malaysia", studi kasus ini berkaitan dengan 13 masalah yang dihadapi oleh
UKM dan memberikan beberapa rekomendasi yangvalid untuk menyelesaikan masalah yang ada di dalam bisnis bakery. Analisis kasus dan temuan mengungkapkan bahwa UKM memiliki strategi pemasaran terstruktur dan kebutuhan tambahan di bidang kemasan, nilai tambah untuk produk bakery, fokus pada promosi dan strategi iklan yang tepat. Lebih lanjut, analisis menunjukkan bahwa cakupan lebih dari jual untuk produk roti, jumlah meningkat pusat distribusi dan insentif yang tepat untuk agen pasti dapat meningkatkan pemasaran produk roti. Pradhika Rhena (2015) dengan judul penelitian "Manajemen Usaha Rumah Tangga Kerupuk Ikan dan Rengginang para Masyarakat di Desa Pabayen Kecamatan Tambakboyo Kabupaten Tuban", tujuan dari penelitian ini adalah untuk mendiskriptifkan dan menganalisis: (1) manajemen proses pembuatan kerupuk ikan, dan (2) manajemen proses pembuatan rengginang. Jenis penelitian ini dilakukan dalam penelitian ini adalah penelitian deskriptif kualitatif dengan lokasi penelitian pada pengusaha kecil pembuatan kerupuk di Desa Pabayen Kecamatan Tambakboyo Kabupaten Tuban. Teknik Pengembilan data menggunakan teknik observasi lapangan, wawancara dan dokumentasi. Hasil penelitian menunjukkan bahwa manajemen usaha kerupuk ikan dan rengginang melalui proses pemilihan bahan, pengolahan bahan, pengemasan bahan, dan proses pendistribusian masih menggunakan cara tradisional. Penelitian yang sama yang dilakukan oleh Budasih NL (2014), dengan judul penelitian "Strategi Pemasaran Produk Olahan Jamur Tiram pada Kelompok Wanita Tani (KWT) Spora Bali", penelitian ini bertujuan untuk mengetahui kendala yang dihadapi petani jamur tiram pembudidaya serta produsen produk olahan jamur tiram milik Kelompok Wanita Tani (KWT) Spora Bali. Hasil penelitian menunjukkan bahwa berdasarkan analisis internal, jamur tiram

p.ISSN: $2407-800 X \quad$ e.ISSN: 2541-4356 
bisnis pengolahan KWT Spora Bali pada posisi rata-rata dalam kekuatan dan kelemahan. Kekuatan utama KWT Spora Bali adalah dalam variasi produk. Kelemahan utama dari KWT Spora Bali adalah harga jual produk. Berdasarkan analisis dari lingkungan eksternal, bisnis tiram pengolahan jamur KWT Spora Bali mengambil keuntungan dari kesempatan untuk mengatasi ancaman yang dihadapi oleh KWT Spora Bali. Kesempatan utama KWT Spora Bali meningkat permintaan pelanggan. Adapun ancaman utama KWT Spora Bali meningkat biaya produksi. Analisis SWOT menemukan 6 strategi alternatif yaitu: peluang terbuka untuk kerjasama dengan pihak lain yang terkait dengan distribusi produk, meningkatkan penjualan promosi atau penyebaran informasi produk, untuk meningkatkan penampilan produk melalui perbaikan kemasan, mencari informasi pasar dengan menggunakan teknologi informasi, berusaha untuk menjaga kualitas produk dan meningkatkan efisiensi dan efektivitas dalam pemasaran produk. Hasil analisis QSPM menunjukkan bahwa strategi adalah prioritas utama untuk meningkatkan penampilan produk melalui perbaikan kemasan untuk produk yang dihasilkan. strategi ini bisa dilakukan dengan memperbarui desain, warna, dan termasuk merek yang telah ditetapkan bersama dengan tanggal kadaluarsa dan izin dari Departemen Kesehatan.

Menurut Hendro

(2011:67), kewirausahaan adalah suatu kemampuan untuk mengelola sesuatu yang ada didalam diri anda untuk dimanfaatkan dan ditingkatkan agar lebih optimal (baik) sehingga bisa meningkatkan taraf hidup anda dimasa datang.

Menurut Buchari Alma Business plan (2007:54), adalah dokumen tertulis yang disiapkan oleh wirausaha yang mengambarkan semua unsur-unsur yang relevan baik internal maupun eksternal mengenai perusahaan untuk memulai sewaktu usaha.
Menurut Kotler (2007:10), strategi adalah suatu rencana permainan untuk mencapainya. Setiap bisnis harus merancang strategi untuk mencapai tujuannya, yang terdiri dari strategi pemasaran dan strategi teknologi, serta strategi penetapan sumber yang cocok.

Pemasaran menurut Muhammad Firdaus (2007:161), pemasaran merupakan salah satu kegiatan pokok yang harus dilakukan oleh para pengusaha termasuk pengusaha tani (agribusinessman) dalam usahanya untuk mempertahankan kelangsungan hidupnya (survival), untuk mendapatkan laba, dan untuk berkembang.

Menurut Daryanto (2012:5), pemasaran merupakan bagian yang penting dengan pasar, karena pasar yang ada sekarang merupakan pasar pembeli dimana terjadinya transaksi jual beli tergantung pada keputusan pembeli sendiri, sehingga pasar yang ada sangat dipengaruhi oleh perilaku para konsumen dan yang penting perusahaan sebagai yang menawarkan barang hanya bisa mengikuti kehendak konsumen dan bagaimana mengatasi pesaing-pesaing dari perusahaan yang menciptakan barang sejenis

Menurut Sofjan Assauri (2010:167), strategi pemasaran pada dasarnya adalah rencana yang menyeluruh, terpadu dan menyatu dalam bidang pemasaran, yang memberikan panduan tentang kegiatan yang akan dijalankan untuk dapat tercapainya tujuan pemasaran suatu perusahaan.

Menurut Indriyo Gitosudarmo (2012:150), bauran pemasaran merupakan alat yang dapat dipergunakan oleh pengusaha untuk mempengaruhi konsumennya. Menurut Jumingan (2009:72), strategi pemasaran merupakan cara untuk menciptakan dan mempertahankan pelanggan demi mendapatkan laba.

Pengertian produk (product) menurut Indriyo Gitosudarmo (2012:215), adalah segala sesuatu yang dapat 
diharapkan dapat memenuhi kebutuhan manusia ataupun organisasi.

Menurut Kotler (2002) dalam Doni Hariadi (2013) harga adalah jumlah uang yang dibebankan atau dikenakan atas sebuah produk atau jasa.

Menurut Daryanto (2012:64), saluran distribusi adalah saluraan yang dipakai oleh produksen untuk menyalurkan barang hasil produksinya kepada konsumen, baik berpindahnya hak (pengusaan) hingga pemindahan barang maupun hanya pemindahan hak kepemilikannya.

Menurut Basu Swasta (2001) dalam Rusmini (2013:74), promosi adalah arus informasi atau persuasi suatu arah yang dibuat untuk mengarah seseorang atau organisasi kepada tindakan yang menciptakan pertukaran dalam pemasaran.

Usaha Kerupuk Multisari merupakan industri yang begerak dalam menghasilkan kerupuk. Usaha Kerupuk Multisari mulai pada tahun 2005 oleh Ibu Yusminar dan keluarganya. Usaha kerupuk multisari ini berada di Jalan Utama Pangkalan Batang Gang Setia Budi Desa Pangkalan Batang, Kecamatan Bengkalis. Kerupuk yang dihasilkan oleh Usaha kerupuk Multisari adalah: kerupuk terasi sagu, kerupuk ikan parang dan kerupuk udang.

\section{METODE}

Bagan alir kegiatan strategi pemasaran usaha Kerupuk Multisari dari awal pelaksanaan hingga penyelesaian. Rencana penyelesaian proyek yang dihasilkan adalah adanya peningkatan strategi pemasaran melalui strategi bauran pemasaran yaitu Produk (Product), Harga (Price), Tempat (Place), Promosi (Promotion). Pelaporan pelaksanaan proyek ini akan dilaporkan setiap seminggu sekali, bertujuan untuk mengetahui tepat atau tidak nya strategi yang digunakan dalam memasarkan produk serta kerupuk apa yang paling diminati oleh konsumen.

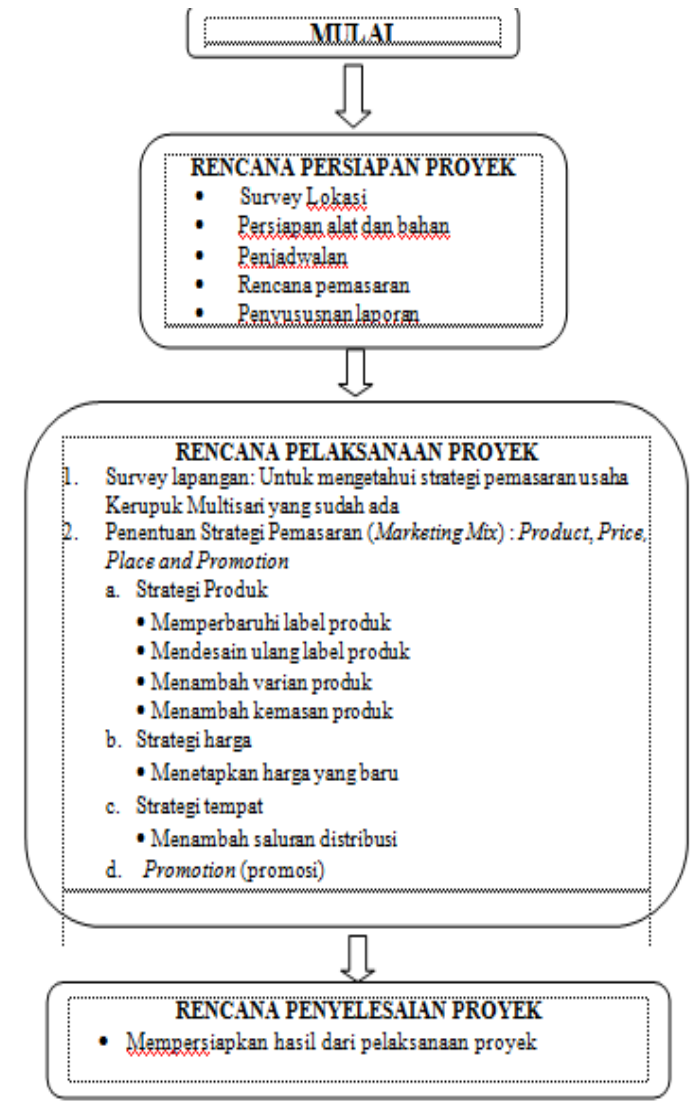

HASIL

Kegiatan yang dilakukan penulis dalam melaksanakan Strategi Pemasaran Usaha Kerupuk Multisari ini adalah, penulis berusaha untuk mengembangkan strategi pemasaran dari produk yang dihasilkan oleh usaha Kerupuk Multisari. Ada beberapa produk yang dihasilkan oleh usaha Kerupuk Multisari yakni kerupuk sagu, kerupuk ikan parang dan kerupuk udang, yang dimana dalam pemasaran usaha Kerupuk Multisari ini penulis menetapkan salah satu bagian dari strategi pemasaran yakni bauran pemasaran (marketing mix), dengan menggunakan bauran pemasaran 4P (Product, Price, Place dan Promotion).

Pada tahap persiapan proyek ini terdapat beberapa kegiatan yang dilakukan strategi pemasaran usaha Kerupuk Multisari yaitu sebagai berikut :

1. Analisa strategi pemasaran

Pada tahap persiapan proyek yang dilakukan pertama adalah melakukan wawancara dengan pemilik usaha kerupuk multisari yang bertujuan untuk 
mengetahui strategi pemasaran yang selama ini diterapkan oleh usaha Kerupuk Multisari.

\section{Produk (Product)}

Setelah dilakukan analisa, tahap persiapan berikutnya adalah dilakukan rancangan pengembangan Strategi Pemasaran Usaha Kerupuk Multisari, untuk produk adalah mendesain ulang kemasan produk: mendesain ulang label produk dengan menambah daftar harga kerupuk dan menambah beberapa slogan pada label produk, memperbaruhi label produk, mencetak label dalam bentuk stiker berdasar label yang telah didesain ulang, memperbaruhi kemasan yaitu kemasan produk ukuran 20.30.08 dan kemasan ukuran 28.17.10 untuk kerupuk mentah sedangkan untuk kerupuk siap saji penulis mempersiapkan kemasan ukuran 20.30.08 dan kemasan ukuran $1 / 2 \mathrm{Kg}$.

3. Harga (Price)

Tahap persiapan proyek yang dilakukan penulis adalah menetapkan harga baru untuk Kerupuk Multisari dengan menggunakan metode penetapan harga penetration princing yaitu metode penetapan harga serendah-rendahnya, yang dimana dalam hal ini agar berhasil diperlukan beberapa persyaratan yakni pengalaman produksi mampu menekan biaya produksi dan distibusi dan harga yang rendah tidak menarik bagi para pesaingnya ( Indriyo, 2012:141).

4. Place (Tempat)

Melakukan survey terlebih dahulu saluran distribusi/ outlet yang bersedia menjadi pengecer produk dari usaha Kerupuk Multisari, dari hasil survei yang dilakukan saluran distribusi untuk usaha Kerupuk Multisari dilihat dari saluran pemasaran konsumen menggunakan saluran pemasaran $\quad 0$-tingkat dan 1-tingkat, dapat terlihat pada gambar berikut:
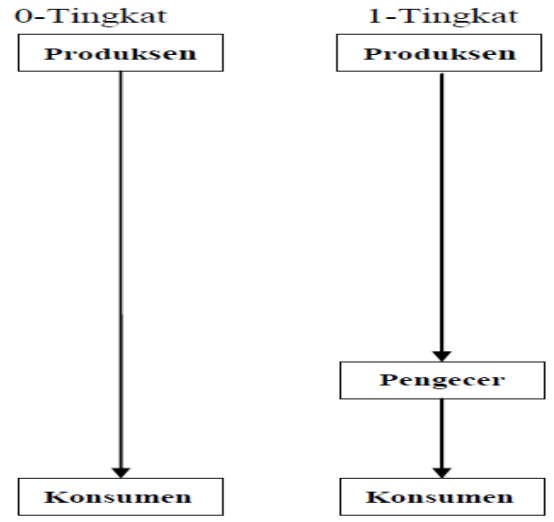

Gambar 1: Saluran Pemasaran Konsumen Sumber: Data Olahan

\section{Promotion (Promosi)}

Tahap persiapan proyek yang dilakukan penulis adalah menetapkan promosi apa saja yang akan dilakukan pada saat melaksanakan proyek akhir, promosi yang akan dilakukan nantinya adalah promosi dalam bentuk periklanan, yakni iklan dimedia sosial dalam bentuk (SMS, Facebook dan BBM), iklan melalui spanduk dan pameran, promosi selanjutnya adalah promosi penjualan dan penjualan langsung.

\section{Pelaksanaan Proyek}

1. Hasil analisa strategi pemasaran Dari wawancara yang dilakukan penulis dengan pemilik usaha Kerupuk Multisari tentang strategi pemasaran segmentasi pasar, target pasar dan posisi pasar dapat dilihat sebagai berikut:

a. Segmentasi Pasar (Segementting)

Segmentasi pasar usaha Kerupuk Multisari adalah menggunakan segmentasi geografis, segmentassi pasar fsikografis dan segmentasi pasar prilaku, namun segmentasi pasar yang difokuskan oleh usaha Kerupuk Multisari ini adalah segmentasi pasar demografi, karena pada segmentasi pasar demografi ini kerupuk multisari mendapatkan perkembangan dalam memasarkan produk, bisa dikatakan sumber utama penghasilan. segmentasi pasar demografi, dimana pada segmentasi pasar demografi, dapat dikatakan 
semua usia, dan gender menyukai kerupuk multisari, kemudian dengan pendapatan yang rendahpun konsumen bisa mendapatkan kerupuk multisari ini, karena harga yang disajikan tidak terlalu mahal, terjangkau untuk semua kalangan, selanjutnya semua dari kelas sosial juga mengkonsumsi produk dari usaha Kerupuk Multisari ini, karena produk yang disajikan merupakan makanan ringan khas Indonesia, sehingga banyak yang menyukai produk tersebut.

b. Target Pasar (Targetting)

Usaha Kerupuk Multisari mempunyai terget pasar atau sasaran pasar pada semua jenis usia dan semua gender, pendapatan mulai dari pendapatan rendah hingga pendapatan tinggi.

c. Posisi Pasar (Positioning)

Posisi pasar adalah cara produk didefinisikan oleh konsumen atas atribut penting atau tempat yang diduduki produk di pikiran konsumen dibandingkan produk saingan. Pada saat ini usaha Kerupuk Multisari merupakan usaha kerupuk yang pertama yang memproduksi kerupuk dengan rasa terasi, ini bertujuan agar usaha Kerupuk Multisari mendapat posisi penting dalam pasar dan selalu mendapat permintaan dari konsumen, selain itu juga salah satu upaya pemilik usaha Kerupuk Multisari mendapatkan perhatian dari konsumen adalah dengan mengikuti pameran makanan khas, hal ini bertujuan agar produknya semakin terkenal dan menjadi leader bagi pesaing lain.

\section{Produk (Product)}

Pada tahap ini dilakukan peningkatan label yang telah didesain ulang, dicetak dengan menggunakan kertas stiker dan di tempel di luar kemasan kerupuk yang sudah dikemas. Selain itu juga dilakukan pembaharuan produk yang dimana dilakukan pemasaran produk kerupuk dalam bentuk instan atau siap saji, proses pengemasannya yaitu dari kerupuk yang telah digoreng dan dikemaskan kedalam kemasan dengan ukuran kemasan 20.30.10 dan kemasan ukuran $1 / 2 \mathrm{Kg}$ dan diberi label, setelah semua kerupuk dikemas, kerupuk siap dipasarkan kesemua saluran distribusi yang baru. Berikut adalah gambar desain label yang diperbarui dengan meletakkan daftar harga kerupuk dan menambahkan slogan.

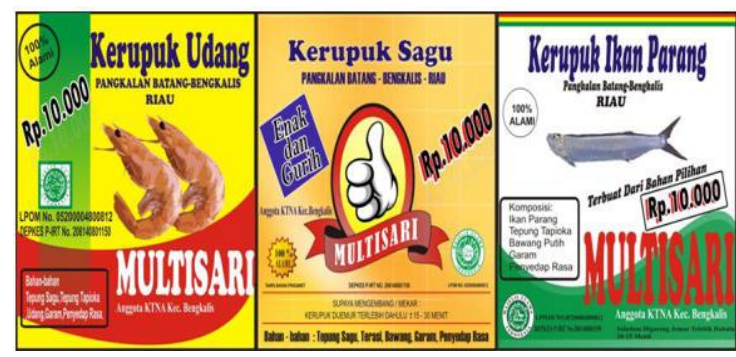

Gambar 2: Label kerupuk mentah kemasan ukuran 20.30.08 yang diperbarui Sumber: Data Olahan

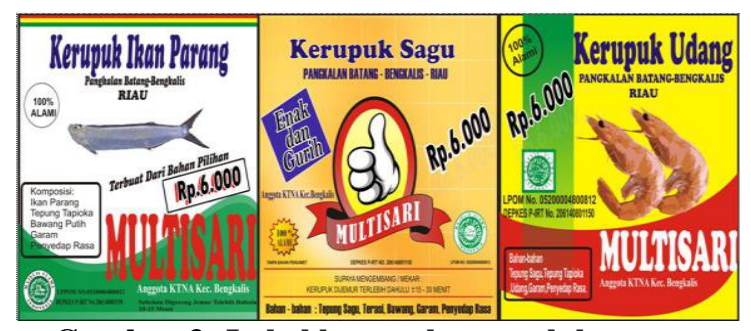

Gambar 3: Label kerupuk mentah kemasan ukuran 28.17.10 yang diperbarui Sumber: Data Olahan

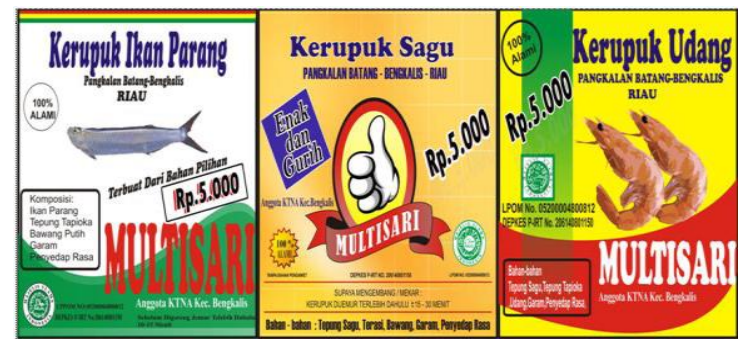

Gambar 4: Label kemasan kerupuk instan kemasan ukuran 20.30.08 yang didesain ulang Sumber: Data Olahan

3. Harga (Price)

Untuk pentapan harga, menetapkan harga berdasarkan metode Penetration Princing yaitu metode penetapan harga serendah rendahnya, yang dimana dalam hal ini agar berhasil diperlukan beberapa persyaratan yakni pengalaman produksi mampu menekan biaya produksi dan distibusi dan harga yang rendah tidak 
menarik bagi para pesaingnya.

4. Tempat (Place)

Setelah melakukan survei terdapat sebanyak 75 lokasi distribusi yang baru untuk usaha kerupuk Multisari dengan lokasi yang strategis dan tempat yang tepat untuk melakukan penjualan kerupuk dari usaha Kerupuk Multisari.

5. Promosi (Promotion)

Strategi promosi yang dilakukan penulis selama melaksanakan proyek akhir strategi pemasaran usaha Kerupuk Multisari ini adalah sebagai berikut:

a. Promosi melaui iklan dimedia sosial SMS (Short Messenger Service)

b. Promosi melaui iklan dimedia sosial BBM (Blackberry messenger)

c. Promosi menggunakan iklan dimedia sosial Facebook

d. Promosi melalui baliho

e. Promosi melalui expo

f. Promosi melalui baliho

\section{Penyelesaian Proyek}

Pada tahap penyelesaian proyek ini dapat dilihat perbedaan produk, harga, tempat dan promosi yang dilakukan yakni: untuk produk perubahan desain label, penambahan variasi produk serta penambahan kemasan yang digunakan. Untuk harga pada, penetapan harga sudah menerapkan strategi Penetration Princing sehingga Usaha Multisari mengetahui strategi penetapan harga yang tepat. selain itu dari sisi saluran distribusi terjadi penambahan lokasi pemasaran sebanyak 75 lokasi pemasaran dan 2 saluran distribusi (saliran 0-tingkat dan 1-tingkat), kemudian untuk promosi yakni promosi melalui iklan, promosi secara langsung dan penjualan langsung.

\section{PEMBAHASAN}

Berdasarkan uraian tersebut dari penelitian yang disusun oleh penulis tentang rancangan strategi pemasaran usaha kerupuk multisari yaitu: Analisa strategi pemasaran usaha Kerupuk Multisari merupakan hal pertama yang harus dilakukan untuk mengetahui strategi pemasaran yang telah digunakan ditinjau dari STP (Segmentting, Targetting dan Posisioning), segmentasi pasar yang difokuskan oleh usaha Kerupuk Multisari adalah segmentasi pasar demografis karena produk Kerupuk Multisari ini disukai oleh semua jenis usia, gender, pendapatan dan kelas sosial. Target pasar yang difokuskan oleh usah Kerupuk Multisari adalah target pasar demografis karena tingkat permintaan dari semua usia, jenis kelamin, semua pendapatan dan kelas sosial. Posisi pasar yang difokuskan oleh usaha Kerupuk Multisari adalah menjadi usaha Kerupuk Multisari yang memproduksi kerupuk dengan rasa terasi, kemudian usaha yang dilakukan untuk menarik perhatian konsumen adalah dengan mengikuti pameran makanan khas.

Strategi produk yang dilakukan pada proyek akhir untuk produk adalah mendesain ulang label dengan menambah daftar harga kerupuk dan beberapa slogan pada label produk, memperbaruhi label produk yakni mencetak label dalam bentuk stiker yang ditempatkan diluar kemasan produk, menambah pemasaran kemasan produk yang sebelumnya usaha Kerupuk Multisari hanya memasarkan satu bentuk kemasan produk, sehingga ditambah dengan kemasan produk yang lebih kecil atau yang lebih ekonomis, selain itu juga menambah variasi dari Kerupuk Multisari dengan memasarkan kerupuk dalam bentuk siap saji. Strategi penetapan harga yang dilakukan adalah menetapkan harga produk yang baru berdasarkan metode penetapan harga penetration princing yakni penetapan harga yang serendah-rendahnya. Strategi tempat pemasaran yang dipilih penulis adalah lokasi yang strategis dengan pangsa pasar yang banyak, dimana selama melaksanakan proyektelah didapat sebanyak 75 lokasi distribusi yang bersedia menjadi pengecer dengan menggunakan 2 jenis saluran distribusi (o-tingkat dan 1tingkat). Strategi promosi yang dikembangkan adalah promosi melaui iklan seperti BBM, SMS dan facebook, baleho dan expo selain itu penulis juga melakukan

p.ISSN: $2407-800 X \quad$ e.ISSN: 2541-4356 
promosi penjualan dan personal selling dan penjualan langsung kepada konsumen.

Dari hasil penyelenggaraan dan kesimpulan di atas, berikut terdapat beberapa saran yang dapat disampaikan: Bagi pemilik usaha Kerupuk Multisari, dalam melakukan pemasaran kedepannya sebaiknya menggunakan strategi pemasaran yang telah dirancang dan dikembangkan sehingga dapat berdampak positif terhadap peningkatan usaha. Bagi UMKM yang sejenis, dapat mengimplementasikan pengembangan strategi pemasaran yang telah dilakukan pada Usaha kerupuk Multisari sehingga dapat meningkatkan daya saing usaha.

\section{SIMPULAN}

Berdasarkan uraian di atas, maka dapat disimpulkan bahwa kenaikan proyek ini dalam bentuk morfinasi strategi pemasaran melalui strategi bauran pemasaran pada kerupuk mikro Mikro dan Menengah Multisari dengan disain label, ukuran kemasan dan diversifikasi produk, dan peningkatan promosi. Proyek Pelaporan terdiri dari pelaporan Strategi Pemasaran Bisnis dan kegiatan pelaporan Strategi Pemasaran Bisnis kerupuk Multisari.

\section{DAFTAR RUJUKAN}

Alma, Buchari. 2010. Kewiraausahaan, Bandung. Alfabeta.

Assauri, Sofjan. 2010. Manajemen Pemasaran (Dasar, Konsep \& Strategi). Cetakan ke-10, PT. RAJA GRAFINDO PERSADA, Jakarta.

Budasih. 2007. Manajemen Pemasaran. Edisi 12. Cetakan ke-2. Jilid 1. Indonesia, PT. Indeks.. 2014. Strategi PemasaranProduk Olahan Jamur Tiram pada Kelompok Waanita Tani (KWT) Spora Bali. Jurnal Manajemen Agribisnis.Vol. 2 No. 2.

Daryanto. 2012. Sari Kuliah Manajen Pemasaran. Bandung, CV Yrama Widya.
Firdaus, Muhammad. 2007. Manajemen Agribisnis. Edisi 1. Cetakan-3,PT. Bumi Aksara, Jakarta.

Gitosudarmo, Indriyo. 2012. Manajemen Pemasaran. Edisi Kedua. Cetakan ke2, BPFE, Yogyakarta.

Hendro. 2011. Dasar-Dasar Kewirausahaan, Penerbit Erlangga, Jakarta.

Jumingan. 2009. Studi Kelayakan Bisnis (teori pembuatan proposal kelayakan). Edisi-1. Cetakan-1, Bumi Aksara, Jakarta.

Kiurmasi, S. 2014. Marketing Strategies to improve the sales of bakery products of small-medium enterprise (SMEs) in Malaysia. Internasional Food Research Journal. Vol. 21 No. 21012107.

Kotler, Philip dan Lane, Keller, Kevin. 2007. Manajemen Pemasaran. Edisi

12. Cetakan ke-2. Jilid 1. Indonesia, PT. Indeks.

Pradhika, Rhena. 2015. Manajemen Usaha Rumah Tangga Kerupuk Ikan dan Rengginang para Masyarakat di Desa Pabeyen Kecamatan Tambakboyo Kabupaten Tuban. Jurnal Boga. Vol. 4. No. 3.

Rusmini. 2013. Strategi Pemasaran Sebagai Dasar Peningkatan Respons Konsumen. Jurnal Pengembangan Humaniora. Vol.13 No.1 Hal.74. 